\begin{tabular}{|l|l|l||}
\hline \multicolumn{2}{|c|}{ PublisherInfo } \\
\hline \hline PublisherName & $:$ & BioMed Central \\
\hline \hline PublisherLocation & $:$ & London \\
\hline \hline PublisherImprintName & $:$ & BioMed Central \\
\hline \hline
\end{tabular}

\title{
Risk of intraparenchymal stroke increased by low saturated fat intake in women
}

\begin{tabular}{||l|l|l||}
\hline \multicolumn{2}{|c||}{ ArticleInfo } \\
\hline \hline ArticleID & $:$ & 31 \\
\hline \hline ArticleDOI & $:$ & $10.1186 /$ cvm-2001-72104 \\
\hline \hline ArticleCitationID & $:$ & 72104 \\
\hline \hline ArticleSequenceNumber & $:$ & 10 \\
\hline \hline ArticleCategory & $:$ & Paper Report \\
\hline ArticleFirstPage & $:$ & 1 \\
\hline \hline ArticleLastPage & $:$ & 1 \\
\hline \hline & & RegistrationDate : 2001-10-18 \\
ArticleHistory & $:$ & Received $\quad: 2001-3-7$ \\
\hline \hline ArticleCopyright & $:$ & Biomed Central Ltd2001 \\
\hline \hline
\end{tabular}




\begin{tabular}{|l|l|l|}
\hline ArticleGrants & $:$ & \\
\hline \hline ArticleContext & $:$ & 1306322 \\
\hline
\end{tabular}

Joanna Lyford, Aff1

Corresponding Affiliation: Aff1

Aff1 MedWire, UK

Keywords

Cerebral hemorrhage, diet, dietary fats, proteins, stroke

\section{Context}

This paper looked at women's intake of saturated fat and their risk of intraparenchymal hemorrhage.

\section{Significant findings}

Analysis revealed that women in the lowest quintile of energy-adjusted saturated fat intake were at higher risk of intraparenchymal hemorrhage, especially if they are hypertensive, compared with women in all higher quintiles, with a relative risk of 2.36. For trans unsaturated fat the relative risk was 2.50 .

\section{Comments}

Study co-author Meir Stampfer said: "Given how much fat we eat in the United States, this study does not change our general goal of reducing saturated fat. However, for people with high blood pressure, the goal should not be an extremely low-fat diet. A more moderate approach may be sufficient to get the benefit for coronary disease without incurring the risk of hemorrhagic stroke." He added that the findings probably also apply to men. In an accompanying editorial, Margo Denke expressed doubts over the validity of the questionnaire used in the study, as well as the methods used to adjust for other cardiovascular risk factorsshe writes. "My suspicion is that the truth regarding the association between dietary factors and intraparenchymal hemorrhage risk is entangled in a web of ethnic differences in 
intracerebral hemorrhage, historical differences in pre-World War II protein adequacy of diets, differences in mineral intake associated with dairy and animal meat diets, and chance findings embedded in an imprecise tool used to measure dietary intake."

\title{
Methods
}

Dietary questionnaires were completed by 85,764 women in the Nurses' Health Study cohort in 1980. From these fat and protein intake were calculated. The subjects were aged between 34 and 59 years and free of diagnosed cardiovascular disease and cancer. By 1996, there were a total of 690 strokes, including 74 intraparenchymal hemorrhages.

\section{Additional information}

\author{
Denke MA: Dairy products and red meat: midwesterners always knew they were good for \\ something.
}

Circulation 2001, 103:784-786.

\section{References}

1. Iso H, Stampfer MJ, Manson JE, Rexrode K, Hu FB, Hennekens CH, Colditz GA, Speizer FE, Willett WC: Prospective Study of Fat and Protein Intake and Risk of Intraparenchymal Hemorrhage in Women . Circulation . 2001, 103: 856-863.

This PDF file was created after publication. 